\title{
Untangling the Intricacies of Infection, Thrombosis, Vaccination, and Antiphospholipid Antibodies for COVID-19
}

\author{
Nevio Cimolai ${ }^{1,2}$ (D) \\ Accepted: 7 June 2021 / Published online: 22 June 2021 \\ (C) The Author(s), under exclusive licence to Springer Nature Switzerland AG 2021
}

\begin{abstract}
Advanced SARS-CoV-2 infections not uncommonly associate with the occurrence of silent or manifest thrombotic events which may be found as focal or systemic disease. Given the potential complexity of COVID-19 illnesses, a multifactorial causation is likely, but several studies have focused on infection-induced coagulopathy. Procoagulant states are commonly found in association with the finding of antiphospholipid antibodies. The correlation of the latter with thrombosis and/or clinical severity remains controversial. Although measures of antiphospholipid antibodies most commonly include assessments for lupus anticoagulant, anticardiolipin, and anti-ß32-glycoprotein-I antibodies, lesser common antibodies have been detected, and there remains speculation that other yet undiscovered autoimmune thrombotic events may yet be found. The recent discovery of post-vaccination thromboses associated with platelet factor 4 antibody has created another level of concern. The pathogenesis of antiphospholipid antibodies and their role in COVID-19-related thrombosis deserves further attention. The multifactorial nature of thrombosis associated with both infection and vaccination should continue to be studied as new events unfold. Even if a cause-and-effect relationship is variable at best, such dedicated research is likely to generate other valuable insights that are applicable to medicine generally.
\end{abstract}

Keywords COVID-19 $\cdot$ Coronavirus $\cdot$ Thrombosis $\cdot$ Antiphospholipid $\cdot$ Vaccine

\section{Introduction}

The spectrum of disease associated with SARS-CoV-2 infection is considerable ranging from a relatively asymptomatic presentation to multisystem disease and death [1]. In complicated illnesses, thrombosis, thromboembolism, and intravascular events are quite prominent as detailed in most publications [2-4]. Variability in cerebral thrombosis alone has attracted international collaborative study among patients with COVID-19 [5]. Incidences of thrombotic events during COVID-19 or shortly thereafter are reportedly variable [6]. The disease course is potentially complicated by many covariables, and thus the understanding of pathogenesis for thrombosis and related events is accordingly complex [7].

Nevio Cimolai

ncimolai@mail.ubc.ca

1 Faculty of Medicine, The University of British Columbia, Vancouver, BC, Canada

2 Children's and Women's Health Centre of British Columbia, 4480 Oak Street, Vancouver, BC V6H3V4, Canada
Children too with COVID-19 evolve what appears to be a prothrombotic state, but fortunately it is less associated with clinical thrombosis $[8,9]$. It is not surprising that human genetic variability may have a role in ascribing risk for such events [10]. Apart from the issue of thrombosis and infection, recent events have highlighted concerns with thrombosis in the context of COVID-19 vaccination [11]. Preceding the latter, there has already been considerable study on the theme of causation for thrombosis and particularly the potential association with antiphospholipid antibodies [12]. It should also be conceded that outside of the potential for thrombosis-related antibodies, alterations in platelet functionality have also been observed [13]. These events must also be seen in the context of endothelial injury or altered fibrinolysis otherwise [14-16]. Persistence of an anomalous clotting profile in other regards has also been proposed well after acute infections [17].

The concept of antiphospholipid antibody-associated thrombosis is considerably complex, and despite decades of related research, many aspects of such an association continue to attract investigation $[18,19]$. This narrative review examines the existing science in the context of applications to COVID-19. It is evident that the themes of thrombosis with 
either infection or vaccination will open new windows of understanding as scientists and clinicians are attracted to this research on short notice and with intensity given concerns with the current COVID-19 pandemic.

\section{Antiphospholipid Syndrome}

The definition of antiphospholipid syndrome has garnered considerable international attention and has led to at least two major consensus statements from very learned and precise scholars [20-22]. As a syndromic entity, there remains considerable ambiguity as to how any such diagnosis is applied to a given patient. That is, clinical syndromes, including those that span thrombotic illnesses, are often detailed on a collection of presentations with and without supportive laboratory data. As such, there eventually proves to be a range of illnesses that are truly represented until further refinement of either clinical or laboratory diagnostic criteria subsequently become available. The difficulty with precision in the diagnosis of spectral illnesses has considerable history in medicine [23]. One of the most pressing issues is the definition of high accuracy diagnostic laboratory measures. What sometimes appears to be a seemingly logical collection of diseases may eventually prove to have considerable diversity after further investigation and discovery.

The revised classification for antiphospholipid syndrome includes such a combination of clinical and laboratory criteria $[21,22]$. Expert panels propose that at least one clinical and one laboratory criterion is required to establish a diagnosis. The clinical criteria include one or more episodes of vascular thrombosis in any body system in which the disease is corroborated by objective imaging or histopathology. Another clinical criterion includes adverse pregnancy outcomes of varying natures. The laboratory criteria so decided must be one or more of documented lupus anticoagulant, anticardiolipin antibodies, or anti- $\beta_{2}$-glycoprotein-I antibodies in the least and with given minimum diagnostic quantitations. As discussed below, more such putative pathogenic antibodies are being proposed. Whereas these criteria help to narrow the various disease presentations into an identifiable diagnosis, it is acknowledged that the predictive values are potentially quite variable. This is not surprising given that clinical disease entities may span cardiac, neurological, dermatological, renal, and hematological systems alone or in combination. The apparent pathology may be focal or diffuse. Whereas the syndromic aspect of such diagnoses may cause ambiguity, it remains possible that the pathogenesis is quite variable even though it largely attracts immune phenomena and thromboses.

In essence, antiphospholipid syndromes are acquired illnesses associated with thrombotic events and the presence of various measurable serum antibodies that are directed to proteinaceous immunogens and that are linked to anionic phospholipids $[18,19]$. The latter immune interactions are believed to trigger intravascular events that lead ultimately in part to thrombosis and an associated chain of clinical and subclinical events. Rather than a vasculitis per se, the syndrome identifies more as a non-inflammatory vasculopathy whereby the blood vessel wall, in whole and/or involving the endothelium, attracts molecular events that occur during a procoagulant state. As such, the blood vessel may be arterial, venous, or capillary. Thrombocytopenia is not uniform but may occur in a sizeable minority. The ability of animal models to manifest antiphospholipid syndrome has been demonstrated with passive infusions of such diagnostic antibody and with the subsequent observation of thrombosis. There is no doubt that a better understanding of this spectral entity attracts some considerations for active intervention [22].

\section{The Elusive or Surreptitious Antiphospholipid Antibody?}

The definition of antiphospholipid antibodies has a historic progression [18, 19, 24]. The classic representation of an antiphospholipid antibody was discovered at least as early as the twentieth century and as manifested by the cardiolipin non-specific antibody detected among patients with syphilis. Much later, the lupus anticoagulant was coined in the context predominantly of unique rheumatic diseases. By the 1990s, antibodies to $\beta_{2}$-glycoprotein-I continued to add to the compendium of such antibodies. The same latter era ushered in the ability to detect antiphospholipid antibodies by enzyme immunoassays. Generalizing, such antibodies bind to plasma proteins that are phospholipid-binding, although it has been previously believed that some such antibodies have direct phospholipid binding [25]. They may occur alone or in combination, and although there is a general correlation in comparative quantitations, the latter is not always determinable [22]. Adding further complexity to the above, new such potential antibodies have emerged as possible candidates including those directed to prothrombin, phosphatidylserine/ prothrombin complexes, and annexin-V.

The presence of the lupus anticoagulant has a greater specificity and predictive value for the syndrome compared to anticardiolipin antibodies. Furthermore, for what antiphospholipid antibody may exist, there can be considerable variation in the immunoglobulin types, quantitation, and effector functions. The latter has been shown in part through the work of Levy et al. who differentiated antiphospholipid antibodies among patients with either systemic lupus erythematosus or syphilis [25]. Thus, the sensitivity and specificity of antibody detection alone may be fraught with difficulty and thereafter complicate interpretation. A more problematic issue is the occurrence of the clinical syndrome in which there is apparently a seronegative state for such antibodies, thus 
raising the concept that not all antibody targets have yet been defined. For example, while conventionally screening for $\operatorname{IgG}$ or IgM antibodies, the role of $\operatorname{IgA}$ such antibodies can be underestimated. Therefore, even if COVID-19 infection and/ or vaccination attracts any such mechanism for thrombosis, it is conceivable that there may or may not be identifiable antiphospholipid antibodies that correlate with the same.

Mechanistically, it is held that these antibodies interfere with the hematological reactions of various anticoagulants in normal and healthy physiology $[18,19]$. Other cellular events include interactions with endothelial cells, peripheral blood mononuclear series, and platelets in the least. Given the different antibody profiles, such diversity may allow for the understanding of potentially why there may be differential expressions of the clinical syndrome. Nevertheless, there is good reason to believe that the syndrome is not solely an antibodymediate disease(s). As theorized, first events of endothelial disruption, but in the presence of unique antibody, may thereafter lead to thrombosis with or without genetic predisposition. If the latter pathogenesis is true in its simplest description, not all presence of such antibodies will necessarily lead to disease nor will all such disease, if it occurs, be of the same intensity.

Antiphospholipid antibodies may be present in significant quantitations among asymptomatic patients at the time of measure and may persist in the long term without an identifiable related disease $[18,19,26]$. For example, low titres of such antibodies, especially anticardiolipin, may be seen in up to $10 \%$ of normal volunteers. In contrast, the more aggressive 'catastrophic antiphospholipid syndrome' commonly has coidentifiable such antibodies in high quantitation. In the least, more credence is ascribed to the presence of these antibodies in the long term and at least some 12 weeks or more apart in measure. Again, however, the persistence of higher-titred sera for either anticardiolipin antibodies or anti- $\$ 2$-glycoprotein-I antibodies may occur in up to $1 \%$ or more of the general population. Many individuals will have transient rises of such antibodies that may disappear in weeks or months thereafter first detection. The latter is especially more common among $\operatorname{IgM}$ than IgG such antibodies and most often of those with relatively low titres. There does not appear to be an association of lupus anticoagulant and other antiphospholipid antibodies in healthy populations [26]. The application of such antibody determination therefore can be fraught with difficulty. Indeed the plethora of publications on this topic varies greatly in the application of diagnostic antibody thresholds whether for frank disease or for population screening studies [22]. Methodological concerns also attract attention including considerable interlaboratory variability [27]. Risk of disease may depend on having high titres of these antibodies along with a combination of them [22]. In addition, the superimposition of infection on patients with antiphospholipid antibodies may potentially trigger clinical thrombotic events or the antiphospholipid syndrome otherwise including the more advanced presentations [28, 29].

It is well-known that infections, or immune stimulation otherwise, have the potential to raise polyclonal activations and that may non-specifically include various autoantibodies. For example, the genesis of rheumatoid factor or anti-smooth muscle antibody in Mycoplasma pneumoniae infections bears witness to the same [30,31]. Such a reactive genesis is usually followed by transiency in expression, and most patients, or animal models, have a return to baseline. An inherent consideration for polyclonal non-specific immune activation during COVID-19 coincides with the finding of broad autoantibody reactivity when finely screened [32].

Whereas polyclonal activations may arise during the course of infection specifically or non-specifically, a key question is whether the particular infection per se allows for antiphospholipid antibodies to develop after either infection and/or vaccination [24]. This has been a long-standing concern and has attracted some research [33-37]. With both bacterial and vaccine model systems, there is evidence that both bacterial and viral epitopes can attract the development of these antibodies. The nature of such antibodies can vary; they may vary in their specificity, and the genesis can be experimentally related to molecular mimicry. Others hinted that the molecular mechanism of epitope sequence homology may be just as important as attractive changes in conformation of such epitopes that arise during attachment or infection [25, 38]. In these regards, therefore, there is reason to believe that COVID-19 infection or vaccination could at least enact the genesis of antiphospholipid antibodies. Abdel-Wahab et al. conclude that at least for some particularly chronic infections, there is increased risk for the development of antiphospholipid antibodies which are thereafter associated with thrombosisrelated illnesses [37].

\section{Antiphospholipid Antibodies and COVID-19 Infection}

That COVID-19 may include in its manifestations various intravascular coagulopathies is well-established [2]. The latter events are generally a sign of more severe disease, but such consequences can occur at any age or stage of infection. A good example of the latter is the thrombotic events that may occur during COVID-19 in pregnancy whether systemically or focally in the placenta [39]. Within this milieu, it is not a surprise that patients with COVID-19 may develop what are believed to be autoimmune antibodies in a more plenary sense [40, 41].

Antiphospholipid antibodies during COVID-19 infection have already attracted considerable attention [12, 42, 43]. Table 1 exemplifies the nature of data that continues to be accumulated from larger case series. From the outset in 


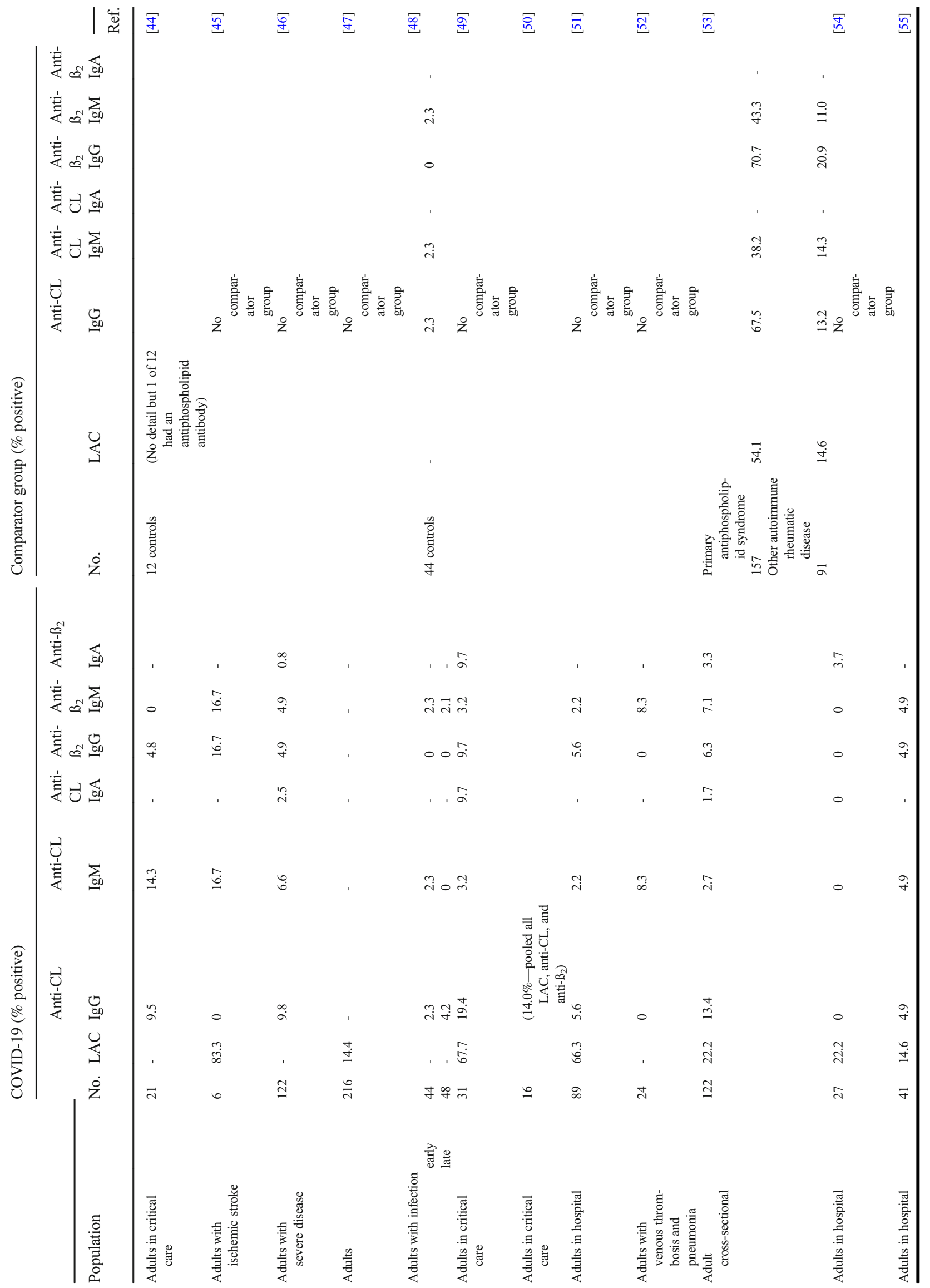




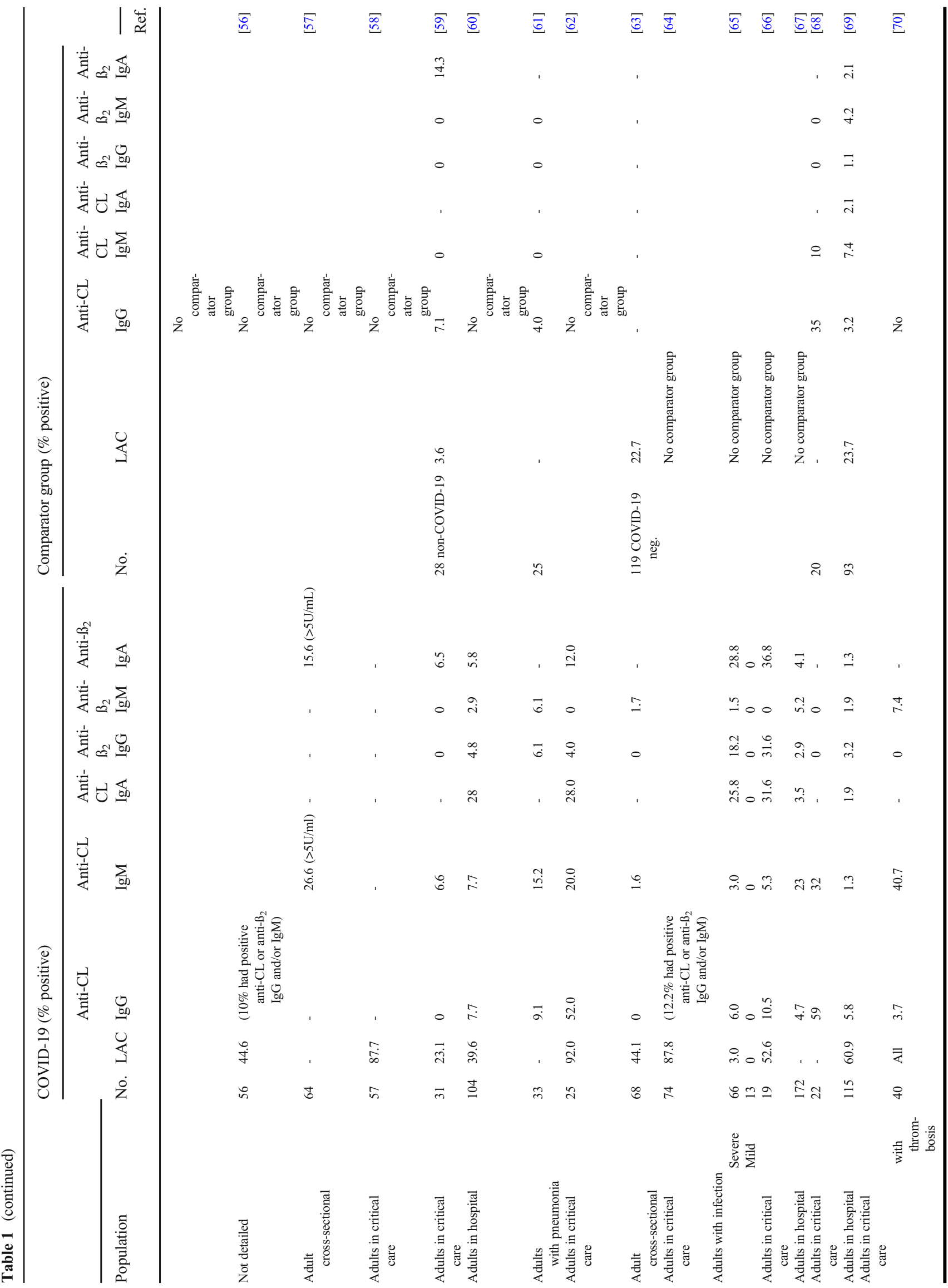




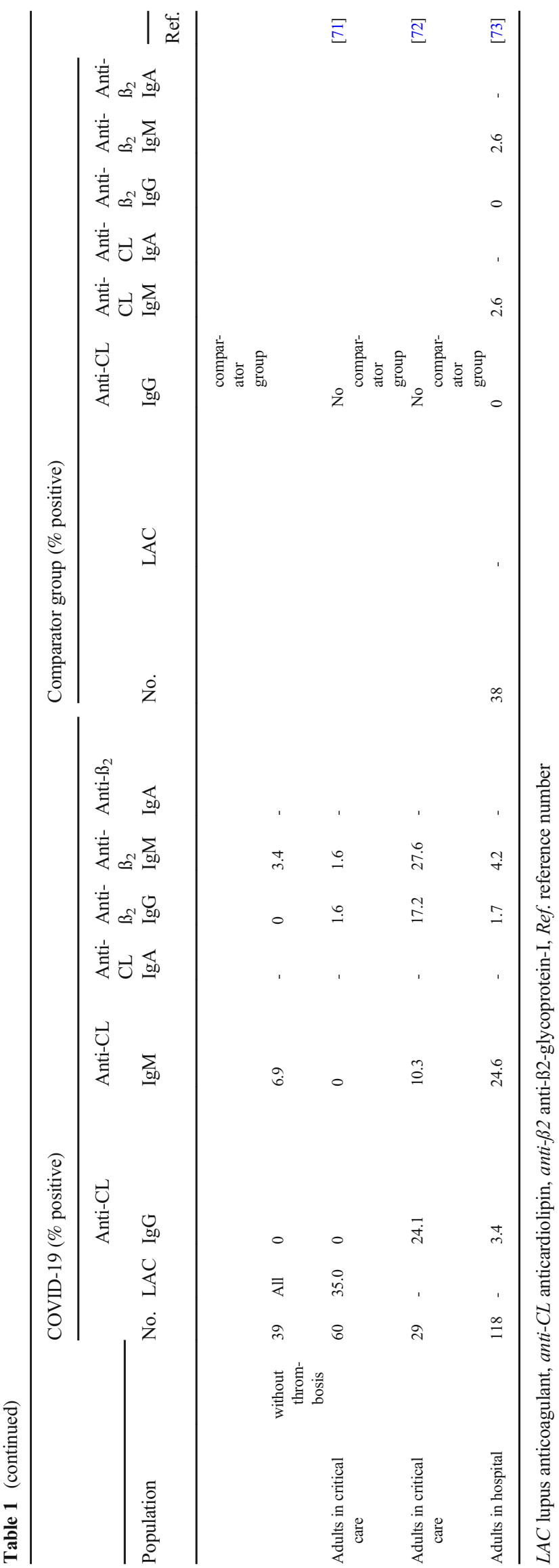

analyzing this compendium of related science, it must be acceded that there is considerable heterogeneity in patient populations and laboratory methodology. Hence, it would be precarious to assume that meta-analysis would be appropriate to apply. A review of these studies, however, nevertheless lends itself to several key observations.

Some have found no consistent association of antiphospholipid antibodies and thrombosis or disease severity $[46,49,51,53,64,69,71]$. Whether detected at the time of first patient presentation or shortly thereafter, such antibody status is time-accrued, maximizes in over 1 month after infection onset, and tends to be transient $[49,68,70]$. The timing of antibody detection therefore must be considered in comparing one study to another. Borghi and colleagues examined reactivity to specific $\beta 2$-glycoprotein-I domains but found a low prevalence [46]. Others find that the presence of such antibodies correlates with severity of COVID-19 $[55,61,68]$. There is a high frequency of antiphospholipid antibodies among patients in intensive care [51, 58, 62, 68, 74]. An association of such antibodies with stroke risk has been suggested [45, 50]. The finding of more than one antiphospholipid antibody in a given patient has been associated with cerebral infarction $[65,66]$. Some studies find a particular association of severe disease with the presence of IgA antiphospholipid antibodies $[42,57]$. Among patients with lupus anticoagulant, one study of critically ill patients found an association of $\operatorname{IgM}$ anticardiolipin antibodies with thrombosis [70]. Antibodies to phosphatidyl serine/prothrombin complex and/or prothrombin appear to be much less common in some but not all studies $[68,69,73]$. Zuo et al. assessed purified immunoglobulin from such patients and found it to promote venous thrombosis in a murine model [67]. Others find that the presence of antiphospholipid antibodies may be a strong predictor of endothelial activation in vitro [73]. It remains tempting to propose that a rapid and severe COVID-19 illness may bear similarity to catastrophic antiphospholipid syndrome when associated antibodies are determined [75].

From the research detailed above, it is safe to say that a conclusive role of antiphospholipid antibodies in the course of COVID-19 is yet to be defined. The rise of antiphospholipid antibodies during COVID-19 infection must be seen in a larger context of the potential rise in autoantibodies generally [32, $61,68,70,72]$.

\section{Heparin-Induced Thrombocytopenia During COVID-19}

As anticoagulants have been used for both treatment and prevention during COVID-19 especially in advanced illnesses, it is not surprising that eventually there would emerge uncommon citations of heparin-induced thrombocytopenias [76-88]. Most of the latter, although not all, have been associated with 
platelet factor 4 antibodies if so assessed. The form of heparin in use has varied in these reports. In some circumstances, the reaction may seemingly occur with the use of heparin for anticoagulation in the face of ECMO [83, 84]. A requisite for alternative anticoagulants is inherent both for treatment and for avoiding any further cascade of the associated pathology $[78,80]$. The specificity of platelet factor 4 antibodies has been questioned $[81,86,87]$. Even more so, the concept of heparin-independent genesis of platelet factor 4 antibody during severe COVID-19 has been discussed [82, 85, 89]. Zhu et al. provide evidence to drive the hypothesis that anti-Spike RBD antibodies may function in part to activate platelets [89]. Jevtic et al. have proposed that screening assays for such antibodies are better confirmed at least with assessments of platelet activation otherwise, but some disparity among these patients has been seen by some $[87,90]$. It is yet unclear if any such inconsistency may be due to varying technologies among laboratories and perhaps non-standardization. Regardless, Preti et al. propose that the incidence of heparin-induced thrombocytopenia is higher in COVID-19 than the background control population [88]. Others rightfully caution in deriving immediate conclusions in regards to pathogenesis [91].

Apart from the above, COVID-19 has been associated with de novo immune thrombocytopenia that may otherwise occur with various viral infections [92, 93]. Again, mechanisms of pathogenesis and their interrelationship with other COVID19-related platelet disorders remain to be defined. One key factor to be considered is the genetic polymorphism among patients and its role in susceptibility [94].

\section{Thrombotic Events and COVID-19 Vaccination}

Concerns for the potential of new COVID-19 vaccine technologies to be associated with autoimmune phenomena are not new [95]. Some other concerns could also be discussed at a theoretical level $[96,97]$. The experience early in the era of COVID-19 vaccines is that any such events would be rare in the context of millions of individuals so immunized to date worldwide and with several vaccine products. Whether any such consequence will manifest itself in the long term remains to be seen and requires judicious review.

One potential such immune reaction has attracted considerable public and scientific attention and has been recently identified predominantly in the context of adenovirusvectored vaccines $[11,98,99]$. These events occur with manifestations of clinical thromboses [100]. The incidence postvaccination with adenovirus vectors is not clear but has variably been suggested to be anywhere between $1 / 20,000$ to $1 / 2,000,000$ vaccinations $[101,102]$. The occurrence of such events has edged toward greater frequency as more data is acquired and a more systematic approach to surveillance is had. In Norway, an assessment post-vaccination with a first dose among 492 healthcare workers did not find clinically relevant thrombocytopenias [103]. A few patients were found to have anti-platelet factor 4 antibodies albeit corroborative findings of platelet activation were lacking. Precedent for concerns regarding post-vaccination hematological events was heralded with somewhat similar vaccine vectors for Ebola [104-108]. The latter studies included considerably fewer patients than would be exposed for COVID-19 vaccination, and adverse events were transient.

Several recent publications expound on these uncommon but yet concerning complications during COVID-19 vaccination series [109-114]. Greinacher et al. describe eleven patients, mainly female, who developed various thromboses within 5 to 16 days after the ChAdOx 1 nCov-19 vaccine [109]. Named immune thrombotic thrombocytopenia, it is proposed that platelet activation is mediated by antibodies to platelet factor 4 . The latter study did not detail an analysis for antiphospholipid antibodies among these patients, but one patient was particularly noted to have a combination of von Willebrand's disease and a preceding anticardiolipin antibody. These patients were also found to have markers of disseminated intravascular coagulopathy. Overall, the disease mimicked that seen with severe heparin-induced thrombocytopenia. Schultz also describe quite a similar presentation among another five patients [110]. Again, antibodies to platelet factor 4 were discovered, but there were no details of antiphospholipid antibody screening. Scully et al. presented findings on another twenty-three similar patients [111]. Twenty-two of the latter had mainly cerebral venous thrombosis. Five of ten patients assessed were found to have lupus anticoagulant, but none were found to have other antiphospholipid antibodies. Tiede et al. detail another five patients but include more variant presentations of thrombosis for arterial, venous, and small vessel disease [112]. Althaus et al. comment on a series of eight patients which included deaths [115]. The latter facilitated postmortem studies which provided evidence of arterial and venous thrombotic events as well as occlusion of renal capillaries. See et al. cite American reports of similar complications after use of the AD26.COV2.S vaccine [113]. Most relevant is the similarity of presentations to those suffering similar illnesses apparently from the ChAdOx1 nCov-19 vaccine. The latter study did not find evidence of antiphospholipid antibody linkages, but did find variable positivity for platelet factor 4 antibody and associated platelet activation studies. A review in Germany associates cerebral venous thrombosis with adenovirus-vectored vaccination although recognizing that this occurs amidst of the background incidence of thrombotic events [114]. Further recommendations for the diagnosis and management of this entity have focused on the finding of platelet factor 4 antibodies [116]. Nevertheless, the latter authors have rightfully acknowledged the potential for other causes of 
thrombosis and thrombocytopenia and have urged caution in the nature of investigations required including the search for antiphospholipid syndrome. Many case reports of a similar event among those receiving adenovirus-vectored vaccine have emerged both in media and scientific journals [117-132]. Typical features include thrombocytopenia, increases in circulating D-dimer, and low fibrinogen levels. Although focus has been made on the central nervous system thromboses, other foci for thrombosis are identified and are evidence of the systemic potential for such toxicity. The case study presented by Ryan et al. illustrates how hematological events may occur in the absence of clinically apparent thrombosis [132]. The latter pattern is uncommonly cited but yet it is unlikely to be found prospectively unless some form of nonthrombotic manifestation becomes apparent. The latter pattern is also a harbinger for many more such patients who likely have a mild form of post-vaccination hematological dyscrasia that is laboratory determined but not clinically evident. As the antiphospholipid syndrome is a spectral illness, it is also likely that post-vaccination hematopathology takes a spectral distribution most of which is subclinical. It is also yet to be seen whether similar post-vaccination events will also follow after use of other adenovirus-vectored vaccines being promoted in either Russia or China [133, 134]. Although adenovirusvectored vaccines differ on some important facets, postvaccine thrombotic events are nevertheless similar [135].

Undoubtedly, the above findings are preliminary and will require international collaboration to further determine the frequency of these events after vaccination and to further explore the pathogenesis. Despite previous large-scale studies of similar vaccine efficacy, the number of patients required to find such uncommon post-vaccination events is greater [136]. Data from a large group of US vaccines, in which most were given RNA vaccines, did not find an association with cerebral thrombosis [137]. One of the latter vaccines was temporally associated with a relapse of thrombotic thrombocytopenic purpura in a case report [138]. The question remains nevertheless as to whether any such processes bear similarity in whole or part to thromboses that are otherwise found during active COVID-19 infections. In particular and with special reference to cerebral thrombosis, retrospective study suggests that COVID-19 in itself attracts an incidence of the latter which exceeds that expected in the general uninfected population $[114,139]$.

As these and other SARS-CoV-2 vaccines emerge, and if thromboses continue to be attributed to the latter, there is a general tendency to ascribe the trigger event to the specific viral components of these vaccines. Molecular mimicry will certainly be at the forefront of hypotheses, and what raises commonality between vaccine and SARS-CoV-2 is Spike protein expression and/or variation [140,141]. Nguyen et al. give credence to the genesis of platelet factor 4 antibodies through potential steric alterations of some antigens [142].
There may be a strong and direct role of platelet factor 4 antibodies, and again an association with antigenic conformational change is posed [115]. Lesser considered components will be the excipients or adjuvants that accompany the same if any. That such components can be immune triggers in themselves has precedence and deserves consideration [23, 143]. The proclivity of anomalous thromboses to young females after some SARS-CoV-2 vaccines raises concern that may or may not bear on pathogenesis. The latter raises theoretical considerations for other immune diseases in which young females more commonly develop antiphospholipid antibodies [144].

Yet other mechanisms of pathogenesis have alternative rationale to be entertained. Khadkhoda's proposal, for example, of an inadvertent vaccinemia draws some preliminary interest but is not without precedence [145]. During the course of creating adenovirus vectors for gene transfer or cancer therapy, early studies recognized that intravenous administration in animal models was associated with thrombocytopenia, autoantibody, endothelial cell activation, dyscoagulation, and/or inflammation in a dose-dependent manner [146-154]. Many of these events extinguished in a time-accrued manner and may be influenced by prior immunity to the vector [148, 153]. Human studies of attempted gene therapy for cancers were well known to have episodes of thrombocytopenia during trials with small patient numbers [155-158]. One such study also identified other alterations relating to coagulation including the presence of lupus anticoagulant [156]. Stone and colleagues ascribed such reduction in circulating platelets to liver sequestration after virus-platelet interactions [159]. The role of vaccinemia has now been furthered by Badbaran et al. who have reported on the presence of vaccine in the bloodstream for days following intramuscular inoculation [160]. Although investigating only a small group of vaccines, vaccinemia was common, and the majority had higher vector copy numbers circulating after 2-3 days rather than immediately after vaccination. Others have suggested a more complex mechanism involving endothelial changes, circulating coagulation factors, and platelet activation [161-165]. A role for the complement system and cytokines also merits consideration [166-168]. Theories of pathogenesis abound [102, 169, 170]. These events and many similar published are intriguing but do not guarantee a mechanism understood for post-vaccination thrombosis. It must be conceded however that veritable concerns about adenoviral vector safety and toxicity were duly being expressed nearly two decades ago albeit with cautious deliberation $[171,172]$.

The occurrence of such thrombotic events has been found at least for the two adenovirus-vectored vaccines most commonly used, and thus it is of interest to at least consider in preliminary form what may be similar or dissimilar among the latter $[110,111,113,141]$. There are indeed more dissimilarities than similarities. The two adenovirus precursors are of 
different lineage. The genes remnant from the given adenovirus precursors and the sequences added thereafter are divergent. The ChAdOx1 nCov-19 vector is constructed with a human tissue plasminogen activator signal sequence [173]. This might engender thoughts of some potential coagulation activity given that tissue plasminogen activator circulates in much higher quantitation in the blood of those with COVID19 infection versus controls [15]. The latter association is much more avid for those patients with worse disease. Expression of this signal peptide modulates immunoreactivity, but it is unclear to what extent any such product will be transcribed [174]. Nevertheless, the AD26.COV2.S vector uses a wild-type signal peptide rather than that of the tissue plasminogen activator [175]. The latter was found to produce a natively-folded Spike protein as the major immunogen. The main commonalities therefore are generically the adenoviral nature of the vector and the production of Spike protein. Kowarz et al. forward a theory that Spike protein variants may be the root cause given transcriptional variability [141]. It is of note that a small study of platelet expression variables after mRNA SARS-CoV-2 vaccination among healthy individuals did not find platelet reactivity or activation [176].

Another phenomenon to consider is that respiratory adenoviral infections, particularly in children, may be accompanied by thrombocytopenia and dyscoagulopathy [177-179]. More prominent such changes are potentially age-dependent which raises the concern for a dose-exposure dependent mechanism similar to that described above in both animal model and human experiments with adenovirus vectors. Lurhuma et al. previously proposed that among patients otherwise with idiopathic thrombocytopenic purpura, circulating immune complexes could be found that included adenoviral antigens [180]. Others could not confirm any such association but then only with the inability to find virus genome in clinical samples [181]. The latter does not exclude the genesis of this disease based on post-infection immune reactivity. Such findings then, if related to similar pathogenesis, point more to the adenoviral nature of the vaccines rather than Spike production per se. One must couch the latter clinical findings against a back-drop however of other viral (non-adenoviral) illnesses that may be associated with thrombocytopenias or dyscoagulation.

The above discussion is very relevant in the context of vaccinemia. Infection of cells during vaccination must be augmented in order to secure a more likely cellular uptake. Despite the latter and even in the event that uptake is relatively inefficient without cellular uptake stimuli, a massive vaccinemia may nevertheless be accompanied by a low grade however inefficient infection of vascular endothelial cells. Past studies of gene therapy using adenovirus vectors are again crucial to this analysis [182-187]. Whereas vascular endothelial infection with adenovirus vectors was established, several attempts were successfully had with the outcome of enhancing endothelial infections and promoting gene therapies. As vector enters the systemic circulation, therefore direct endothelial invasion, infection, and pathological outcomes thereof are at least theoretically possible and beyond. Such a theory at least would implicate vector-driven pathology but would also allow for the consequences of such infection and Spike protein display to enter into a multifactorial causation. Such theory would also explain the role of adenovirus vectors to cause dyscoagulation in other vaccinations, e.g., Ebola virus, and yet draw the potential for variation among these vaccines due to the inherent diversity of the vector construct. This theory could also explain the nonspecificity of site for thrombosis in the vascular endothelial bed, and furthermore explain cerebral thromboses due to the potential effect on brain microvascular endothelium [183].

In the interim, recommendations for clinical and laboratory diagnosis of vaccine-associated thrombosis have emerged [188-190]. Recognition of variation for laboratory diagnostic methods may explain some centre-centre heterogeneity for diagnosis [131, 191]. Treatment of COVID-19 related thrombosis raises some jeopardy since heparin or derivatives as anticoagulants are in common use. Whether for COVID-19 or vaccine-related thrombosis, the use of alternate anticoagulants, and possibly IVIG, should be considered [111, 112, 122, 190, 192-194]. More likely than not, once the pathogenesis of this phenomenon is better understood, other forms of therapy will emerge [122, 195]. Furthermore, changes as to how the vaccines will be recommended and used are likely to occur [196]. Patients at high risk of thrombophilia require particular consideration.

Discussions of this nature are sure to raise issues of vaccine hesitancy, but any such discussion should be seen purely and justly in the eye of scientific endeavor and contribution. Mass vaccination will undoubtedly benefit the populace at large, but as we are already learning, no existing vaccine will be perfect and some may appear less perfect than others over time. There are many aspects of COVID-19-related immunology that have been critically assessed, but the entity of related autoimmunity is relatively in its infancy [197-199]. In the interim, complications of thrombosis whether after infection or vaccination should be embraced as substance for further understandings of pathogenesis since the spin-offs are more likely to be broader than initially presumed. Such interest is more so evident with the potential that SARS-CoV-2 may become resident as the fifth common respiratory endemic coronavirus [200].

\section{Conclusion}

Thrombotic illnesses are common among advanced COVID19 infections. The pathogenesis is likely multifactorial, but study continues to examine unifying hypotheses. The more contemporary finding of thrombosis post-SARS-CoV-2 
vaccination adds further impetus to the research that is required. Antiphospholipid antibodies are commonly found in the sera of those infected, but a bonafide cause-and-effect relationship is yet to be concluded. The diversity of antiphospholipid antibodies variably includes lupus anticoagulant, anticardiolipin, and anti- $\beta_{2}$ glycoprotein-I antibodies alone or in combination. Post-vaccination thrombosis has been associated thus far with antibodies to platelet factor 4 . Disease-related antiphospholipid antibodies are largely transient, but a role during active infection or shortly thereafter cannot be excluded. In the interim, continued research on pathogenesis, disease course, and causation is welcome.

Code Availability Not applicable.

Author Contribution There is one author, and there are no government, industry, or Trust connections.

Funding Funding was not sought for this publication. There is no third party support including that from the pharmaceutical industry.

Data Availability Not required.

\section{Declarations}

Ethics Approval Ethics approval is not required for this review.

Consent to Participate Consent is not required for the review.

Consent for Publication There is only one author.

Conflict of Interest The author declares no conflict of interest.

\section{References}

1. White-Dzuro G, Gibson LE, Zazzeron L, White-Dzuro C, Sullivan Z, Diiorio DA, et al. Multisystem effects of COVID19: a concise review for practitioners. Postgrad Med. 2021;133(1):20-7.

2. Siddiqi HK, Libby P, Ridker PM. COVID-19 - a vascular disease. Trends Cardiovasc Med. 2021;31(1):1-5.

3. Lodigiani C, Iapichino G, Carenzo L, Cecconi M, Ferrazzi P, Sebastian T, et al. Venous and arterial thromboembolic complications in COVID-19 patients admitted to an academic hospital in Milan, Italy. Thromb Res. 2020;191:9-14.

4. Tang N, Li D, Wang X, Sun Z. Abnormal coagulation parameters are associated with poor prognosis in patients with novel coronavirus pneumonia. J Thomb Haemost. 2020;18(4):844-7.

5. Shahjouei S, Tsivgoulis G, Farahmoud G, Koza E, Mowla A, Vafaei Sadr A, et al. SARS-CoV-2 and stroke characteristics: a report from the multinational COVID-19 Stroke Study Group. Stroke. 2021;2020:STROKEAHA120032927. https://doi.org/10. 1161/STROKEAHA.120.032927.

6. Tholin B, Ghanima W, Einvik G, Aarli B, Brønstad E, Skjønsberg $\mathrm{OH}$, et al. Incidence of thrombotic complications in hospitalized and non-hospitalised patients after COVID-19 diagnosis. Br J Haematol. 2021. https://doi.org/10.1111/bjh.17522.
7. Calvisi SL, Ramirez GA, Scavini M, Da Prat V, Di Lucca G, Laurenzi A, et al. Thromboembolism risk is higher among patients with diabetes and COVID-19 and is associated to poor clinical outcome. medRxiv. 2021. https://doi.org/10.1101/2021.04.17. 21255540.

8. Al-Ghafry M, Vagrecha A, Malik M, Levine C, Uster E, Aygun B, et al. Multisystem inflammatory syndrome in children (MIS-C) and the prothrombotic state: coagulation profiles and rotational thromboelastometry in a MIS-C cohort. J Thromb Haemost. 2021. https://doi.org/10.1111/jth.15340.

9. Baker Whitworth H, Sartain SE, Kumar R, Armstrong K, Ballester L, Betensky M, et al. Rate of thrombosis in children and adolescents hospitalized with COVID-19 or MIS-C. Blood. 2021;2020:010218. https://doi.org/10.1182/blood.2020010218.

10. Papadopoulou A, Musa H, Sivaganesan M, McCoy D, Deloukas P, Marouli DE. COVID-19 susceptibility variants associate with blood clots, thrombophlebitis and circulatory diseases. medRxiv. 2021. https://doi.org/10.1101/2021.05.04.21256617.

11. Dinesen Østergaard S, Schmidt M, Horváth-Puhó E, Wernich Thomsen R, Toft SH. Thromboembolism and the AstraZeneca COVID-19 vaccine: side-effect or coincidence. Lancet. 2021. https://doi.org/10.1016/S0140-6736(21)00762-5.

12. Gkrouzman E, Barbhaiya M, Erkan D, Lockshin MD. Reality check on antiphospholipid antibodies in COVID-19-associated coagulopathy. Arthritis Rheum. 2021;73(1):173-80.

13. Zhou Y, Nishikawa M, Kanno H, Xiao T, Suzuki T, Ibayashi Y, et al. The landscape of circulating platelet aggregates in COVID19. medRxiv. 2021. https://doi.org/10.1101/2021.04.29. $21256354 \mathrm{v} 1$.

14. Levy JH, Iba T, Gardiner EE. Endothelial injury in COVID-19 and acute infections: putting the pieces of the puzzle together. Arterioscler Thromb Vasc Biol. 2021;41(5):1174-6.

15. Hammer S, Häberle H, Schlensak C, Bitzer M, Malek NP, Handgretinger R, et al. Severe SARS-CoV-2 infection inhibits fibrinolysis leading to changes in viscoelastic properties of blood clot: a descriptive study of fibrinolysis in COVID-19. Thromb Haemost. 2021. https://doi.org/10.1055/a-1400-6034.

16. McAlpine LS, Zubair AS, Maran I, Chojecka P, Lleva P, Jasne $\mathrm{AS}$, et al. Ischemic stroke, inflammation, and endotheliopathy in COVID-19 patients. Stroke. 2021;2021: STROKEAHA 120031971 . https://doi.org/10.1161/ STROKEAHA.120.031971.

17. Pretorius E, Vlok M, Venter C, Bezuidenhout JA, Iaubscher GJ, Steenkamp J, et al. Persistent clotting protein pathology in Long COVID/post-acute sequelae of COVID-19 (PASC) is accompanied by increased levels of antiplasmin. medRxiv. 2021. https:// doi.org/10.1101/2021.05.21.21257578.

18. Barbhaiya M, Salmon JE, Erkan D. Chapter 87. Antiphospholipid syndrome. In: Firestein GS, et al., editors. Kelley \& Firestein's Textbook of Rheumatology. Philadelphia: Elsevier; 2021.

19. D'Cruz DP, Khamashta MA, Hughes GRV. Antiphospholipid syndrome. In: Ball GV, et al., editors. Oxford Textbook of Vasculitis. 3rd ed. New York: Oxford University Press; 2014.

20. Wilson WA, Gharavi AE, Koike T, Lockshin MD, Branch DW, Piette JC, et al. International consensus statement on preliminary classification criteria for definite antiphospholipid syndrome: report of an international workshop. Arthritis Rheum. 1999;42(7): 1309-11.

21. Miyakis S, Lockshin MD, Atsumi T, Branch DW, Brey RL, Cervera $\mathrm{R}$, et al. International consensus statement on an update of the classification criteria for definite antiphospholipid syndrome (APS). J Thromb Haemost. 2006;4(2):295-306.

22. Tektonidou MG, Andreoli L, Limper M, Amoura Z, Cervera R, Costedoat-Chalumeau N, et al. EULAR recommendations for the management of antiphospholipid syndrome in adults. Ann Rheum Dis. 2019;78(10):1296-304. 
23. Cimolai N. Mast cell biology and linkages for non-clonal mast cell activation and autoimmune/inflammatory syndrome induced by adjuvants. SN Comp Clin Med. 2020;2(11):2310-23.

24. Gharavi AE. Origin of antiphospholipid antibodies. Rheum Dis Clin. 2001;27(3):551-63.

25. Levy RA, Gharavi AE, Sammaritano LR, Habina L, Qamar T, Lockshin MD. Characteristics of IgG antiphospholipid antibodies in patients with systemic lupus erythematosus and syphilis. J Rheumatol. 1990;17(8):1036-41.

26. Vila P, Hernández MC, López-Fernández MF, Batlle J. Prevalence, follow-up and clinical significance of the anticardiolipin antibodies in normal subjects. Thromb Hemost. 1994;72(2):209-13.

27. Connell NT, Battinelli EM, Connors JM. Coagulopathy of COVID-19 and antiphospholipid antibodies. J Thromb Haemost. 2020. https://doi.org/10.1111/jth.14893.

28. Sène D, Piette J-C, Cacoub P. Antiphospholipid antibodies, antiphospholipid syndrome and infections. Autoimmun Rev. 2008;7(4):272-7.

29. Garcia-Carrasco M, Mendoza-Pinto C, Macias-Diaz S, Vasquez de Lara F, Etchegaray-Morales I, Galvez-Romero JL, et al. The role of infectious diseases in the catastrophic antiphospholipid syndrome. Autoimmun Rev. 2015;14(11):1066-71.

30. Cimolai N, Cheong AC. Anti-smooth muscle antibody in clinical human and experimental animal Mycoplasma pneumoniae infection. J Appl Microbiol. 1997;82(5):625-30.

31. Cimolai N, Mah D, Thomas E, Middleton PJ. Rapid immunoblot method for diagnosis of acute Mycoplasma pneumoniae infection. Eur J Clin Microbiol Infect Dis. 1990;9(3):223-6.

32. Wang EY, Mao T, Klein J, Dai Y, Huck JD, Jaycox JR, et al. Diverse functional autoantibodies in patients with COVID-19. Nature. 2021. https://doi.org/10.1038/s41586-021-03631-y.

33. Gharavi EE, Chaimovich H, Cucurull E, Celli CM, Tang H, Wilson WA, et al. Induction of antiphospholipid antibodies by immunization with synthetic viral and bacterial peptides. Lupus. 1999;8(6):449-55.

34. Blank M, Krause I, Fridkin M, Keller N, Kopolovic J, Goldberg I, et al. Bacterial induction of autoantibodies to $\beta_{2}$-glycoprotein-I accounts for the infectious etiology of antiphopholipid syndrome. J Clin Invest. 2002;109(6):797-804.

35. Cruz-Tapias P, Blank M, Anaya J-M, Shoenfeld Y. Infections and vaccines in the etiology of antiphospholipid syndrome. Curr Opin Rheumatol. 2012;24(4):389-93.

36. Asherson RA, Cervera R. Antiphospholipid antibodies and infections. Ann Rheum Dis. 2003;62(5):388-93.

37. Abdel-Wahab N, Talathi S, Lopez-Olivo NM, Suarez-Almazor ME. Risk of developing antiphospholipid antibodies following viral infection: a systematic review and meta-analysis. Lupus. 2018;27(4):572-83.

38. de Laat B, van Berkel M, Urbanus RT, Siregar B, de Groot PG, Gebbink MF, et al. Immune responses against domain I of B(2)glycoprotein I are driven by conformational changes: domain I of $\beta(2)$-glycoprotein I harbors a cryptic immunogenic epitope. Arthritis Rheum. 2011;63(12):3960-8.

39. Cimolai N. A comprehensive analysis of maternal and newborn disease and related control for COVID-19. SN Compr Clin Med. 2021;17:1-23.

40. Chang SE, Feng A, Meng W, Apostolidis SA, Mack E, Artandi $\mathrm{M}$, et al. New-onset IgG autoantibodies in hospitalized patients with COVID-19. medRxiv. 2021. https://doi.org/10.1101/2021. 01.27.21250559v1

41. Pagano S, Yerly S, Meyer B, Juillard C, Suh N, Le Terrier C, et al. SARS-CoV-2-infection as a trigger of humoral responses against apolipoprotein A-1. medRxiv. 2021. https://doi.org/10.1101/ 2021.02.12.21251298v1
42. Zhang Y, Xiao M, Zhang S, Xia P, Cao W, Jiang W, et al. Coagulopathy and antiphospholipid antibodies in patients with COVID-19. N Engl J Med. 2020;382(17):e38(1)-3).

43. Castillo-Martinez D, Torres Z, Amezcua-Guerra LM, Pineda C. Are antiphospholipid antibodies just a common epiphenomenon or are they causative of immune-mediated coagulopathy in COVID-19? Clin Rheumatol. 2021. https://doi.org/10.1007/ s10067-021-05724-5.

44. Amezcua-Guerra LM, Rojas-Velasco G, Brianza-Padilla M, Vásquez-Rangel A, Márquez-Velasco R, Barando-Tovar F, et al. Presence of antiphospholipid antibodies in COVID-19: case series study. Ann Rheum Dis. 2020:annrheumdis-2020-218100. https:// doi.org/10.1136/annrheumdis-2020-218100.

45. Beyrouti R, Adams ME, Benjamin L, Cohen H, Farmer SF, Goh YY, et al. Characteristics of ischaemic stroke associated with COVID-19. J Neurol Neurosurg Psychiatry. 2020;91(8):889-91.

46. Borghi MO, Beltagy A, Garrafa E, Curreli D, Cecchini G, Bodio C, et al. Anti-phospholipid antibodies in COVID-19 are different from those detectable $\mathrm{n}$ the anti-phospholipid syndrome. Front Immunol. 2020;11:584241.

47. Bowles L, Platton S, Yartey N, Dave N, Lee K, Hart DP, et al. Lupus anticoagulant and abnormal coagulation tests in patients with COVID-19. N Engl J Med. 2020;383(3):288-90.

48. Cristiano A, Fortunati V, Cherubini F, Bernardini S, Nuccetelli M. Anti-phospholipids antibodies and immune complexes in COVID-19 patients: a putative role in disease course for antiannexin-V antibodies. Clin Rheumatol. 2021;19:1-7. https://doi. org/10.1007/s10067-021-05580-3.

49. Devreese KMJ, Linskens EA, Benoit D, Peperstraete H. Antiphospholipid antibodies in patients with COVID-19: a relevant observation? J Thromb Hemostat. 2020;18(9):2191-201.

50. Fan S, Xiao M, Han F, Xia P, Bai X, Chen H, et al. Neurological manifestations in critically ill patients with COVID-19: a retrospective study. Front Neurol. 2020;11:806.

51. Ferrari E, Sartre B, Squara F, Contenti J, Occelli C, Lemoel F, et al. High prevalence of acquired thrombophilia without prognosis value in patients with coronavirus disease 2019. J Am Heart Assoc. 2020;9(21):e017773.

52. Galeano-Valle F, Oblitas CM, Ferreiro-Mazón MM, AlonsoMuñoz J, Del Toro-Cervera J, di Natale M, et al. Antiphospholipid antibodies are not elevated in patients with severe COVID-19 pneumonia and venous thromboembolism. Thromb Res. 2020;192:113-5.

53. Gatto M, Perricone C, Tonello M, Bistoni O, Cattelan AM, Bursi $\mathrm{R}$, et al. Frequency and clinical correlates of antiphospholipid antibodies arising in patients with SARS-CoV-2 infection: findings from a multicenter study on 122 cases. Clin Exp Rheumatol. 2020;38(4):754-9.

54. Gutiérrez López de Ocáriz X, Castro Quismondo N, Guerrero EV, Rodriguez Rodriguez M, Ayala Diaz R, Martinez López J. Thrombosis and antiphospholipid antibodies in patients with SARS-CoV-2 infection (COVID-19). Int J Lab Hematol. 2020;42(6):e280-2.

55. Hamadé A, Woehl B, Harzallah I, Talbot M, Tousch J, Jambert L. Antiphospholipid antibodies in patients with coronavirus disease 2019 infection hospitalized in conventional unit. Blood Coagul Fibrinolysis. 2021;32(2):73-9.

56. Harzallah I, Debliquis A, Drénou B. Lupus anticoagulant is frequent in patients with COVID-19. J Thromb Haemost. 2020;18(8):2064-5.

57. Hasan Ali O, Bomze D, Risch L, Brugger SD, Paprotny M, Weber $\mathrm{M}$, et al. Severe COVID-19 is associated with elevated serum IgA and antiphospholipid IgA-antibodies. Clin Infect Dis. 2020;2020: ciaa1496. https://doi.org/10.1093/cid/ciaa1496.

58. Helms J, Tacquard C, Severac F, Leonard-Lorant I, Ohana M, Delebranche X, et al. High risk of thrombosis in patients with 
severe SARS-CoV-2 infection: a multicenter prospective cohort study. Intensive Care Med. 2020;46(6):1089-98.

59. Karahan S, Erol K, Yuksel RC, Artan C, Celik I. Antiphospholipid antibodies in COVID-19-associated pneumonia patients in intensive care unit. Mod Rheumatol. 2021;1:1-10. https://doi.org/10. 1080/14397595.2021.1892257.

60. Le Joncour A, Frere C, Martin-Toutain I, Gougis P, GhillaniDalbin P, Maalouf G, et al. Antiphospholipid antibodies and thrombotic events in COVID-19 patients hospitalized in medicine ward. Autoimmun Rev. 2021;20(2):102729.

61. Pascolini S, Vannini A, Deleonardi G, Ciordinik M, Sensoli A, Carletti I, et al. COVID-19 and immunological dysregulation: can autoantibodies be useful? Clin Trans Sci. 2021;14(2):502-8.

62. Pineton de Chambrun M, Frere C, Miyara M, Amoura Z, MartinToutain I, Mathian A, et al. High frequency of antiphospholipid antibodies in critically ill COVID-19 patients: a link with hypercoagulability? J Intern Med. 2021;289(3):422-4.

63. Reyes Gil M, Barouqa M, Szymanski J, Gonzalez-Lugo JD, Rahman S, Billett HH. Assessment of lupus anticoagulant positivity in patients with coronavirus disease 2019 (COVID-19). JAMA Netw Open. 2020;3(8):e2017539.

64. Siguret V, Voicu S, Neuwirth M, Delrue M, Gayat E, Stépanian A, et al. Are antiphospholipid antibodies associated with thrombotic complications in critically ill COVID-19 patients? Thromb Res. 2020;195:74-6.

65. Xiao M, Zhang Y, Zhang S, Qin Z, Xia P, Cao W, et al. Antiphospholipid antibodies in critically ill patients with COVID-19. Arthritis Rheum. 2020;72(12):1998-2004.

66. Zhang Y, Cao W, Jiang W, Xiao M, Li Y, Tang N, et al. Profile of natural anticoagulant, coagulant factor and anti-phospholipid antibody in critically ill COVID-19 patients. J Thromb Thrombolysis. 2020;50(3):580-6.

67. Zuo Y, Estes SK, Ali RA, Gandhi AA, Yalavarthi S, Shi H, et al. Prothrombotic autoantibodies in serum from patients hospitalized with COVID-19. Sci Transl Med. 2020;12(570):eabd3876.

68. Trahemberg U, Rottapel R, Dos Santos CC, Slutsky AS, Baker A, Fritzler MJ. Anticardiolipin and other antiphospholipid antibodies in critically ill COVID-19 positive and negative patients. Ann Rheum Dis. 2021:annrheumdis-2021-220206. https://doi.org/10. 1136/annrheumdis-2021-220206.

69. Gendron N, Dragon-Durey M-A, Chocron R, Darnige L, Jourdi G, Philippe A, et al. Lupus anticoagulant single positivity at acute phase is not associated with venous thromboembolism or inhospital mortality in COVID-19. Arthritis Rheum. 2021. https:// doi.org/10.1002/art.41777.

70. Vollmer O, Tacquard C, Dieudonne Y, Nespola B, Sattler L, Grunebaum L, et al. Follow-up with COVID-19 patients: LA is transient but other aPLs are persistent. Autoimmun Rev. 2021;20(6):102822.

71. Najim M, Rahhal A, Khir F, Aljundi AH, Yousef SA, Ibrahim F, et al. Prevalence and clinical significance of antiphospholipid antibodies in patients with Coronavirus Disease 2019 admitted to intensive care units: a prospective observational study. Rheumatol Int. 2021. https://doi.org/10.1007/s00296-021-048757.

72. Vlachoyiannopoulos PG, Magira E, Alexopoulos H, Jahaj E, Theophilopoulou K, Kotanidou A, et al. Autoantibodies related to systemic autoimmune rheumatic diseases in severely ill patients with COVID-19. Ann Rheum Dis. 2020;79(12):1661-3.

73. Shi H, Zuo Y, Navaz S, Harbaugh A, Hoy C, Gandhi AA, et al. Endothelial cell-activating antibodies in COVID-19. medRxiv. 2021. https://doi.org/10.1101/2021.01.18/21250041.

74. Frapard T, Hue S, Rial C, de Prost N, Mekontso DA. Antiphospholipid autoantibodies and thrombosis in patients with COVID-19: comment on the article by Bertin et al. Arthritis Rheum. 2021;73(5):897-9.
75. Roncati L, Corsi L, Barbolini G. Abnormal immunothrombosis and lupus anticoagulant in a catastrophic COVID-19 recalling Asherson's syndrome. J Thromb Thrombolysis. 2021. https:// doi.org/10.1007/s11239-021-02444-0.

76. Lozano R, Franco M-E. Incidence of heparin-induced thrombocytopenia in patients with 2019 Coronavirus Disease. Med Clin. 2020;155(9):409-10.

77. Sartori M, Cosmi B. Heparin-induced thrombocytopenia and COVID-19. Hematol Rep. 2021;13(1):8857.

78. Ogawa Y, Nagata T, Akiyama T, Nishida K, Kumasawa J, Kohno $\mathrm{M}$, et al. Argatroban therapy for heparin-induced thrombocytopenia in a patient with Coronavirus Disease 2019. J Thromb Thrombolysis. 2020;50(4):1012-4.

79. Daviet F, Guervilly C, Baldesi O, Bernard-Guervilly F, Pilarczyk E, Genin A, et al. Heparin-induced thrombocytopenia in severe COVID-19. Circulation. 2020;142(19):1875-7.

80. Kewan T, Covut F, Daw H, Haddad A. Heparin-induced thrombocytopenia in a patient with Coronavirus Disease-19: diagnostic and management challenge. Am J Ther. 2020. https://doi.org/10. 1097/MJT.0000000000001282

81. Lingamaneni P, Gonakoti S, Moturi K, Vohra I, Zia M. Heparininduced thrombocytopenia in COVID-19. J Investig Med High Impact Case Rep. 2020;8:1-4.

82. Liu X, Zhang X, Xiao Y, Gao Y, Wang G, Wang Z, et al. Heparininduced thrombocytopenia is associated with a high risk mortality in critical COVID-19 patients receiving heparin-involved treatment. medRxiv. 2020. https://doi.org/10.1101/2020.04.23. 20076851.

83. Bidar F, Hekiman G, Martin-Toutain I, Lebreton G, Combes A, Frère C. Heparin-induced thrombocytopenia in COVID-19 patients with severe acute respiratory distress syndrome: requiring extracorporeal membrane oxygenation: two case reports. J Artif Organs. 2020. https://doi.org/10.1007/s10047-020-01203.

84. Phan XT, Nguyen TH, Tran TT, Huynh T-HT, Hoang T-HT, Nguyen V-CV, et al. Suspected heparin-induced thrombocytopenia in a COVID-19 patient on extracorporeal membrane oxygenation support: a case report. Thromb J. 2020;18(1):37.

85. Madala S, Kryzyzak M, Dehghani S. Is COVID-19 an independent risk factor in heparin-induced thrombocytopenia? Cureus. 2021;13(2):e13425.

86. Riker RR, May TL, Fraser GL, Gagnon DJ, Bandara M, Zemrak WR, et al. Heparin-induced thrombocytopenia with thrombosis in COVID-19 adult respiratory distress syndrome. Res Pract Thromb Haemost. 2020;4(5):936-41.

87. Dragonetti D, Guarini G, Pizzuti M. Detection of anti-heparin-PF4 complex antibodies in COVID-19 patients on heparin therapy. Blood Transfus. 2020;18(4):328.

88. Preti PS, Russo M, Caneva L, Reduzzi M, Calabretta F, Spataro C, et al. Increased prevalence of heparin induced thrombocytopenia in COVID-19 patients. Thromb Res. 2021;203:33-5.

89. Zhu W, Zheng Y, Yu M, Wei J, Zhang Y, Topchyan P, et al. SARS-CoV-2 receptor binding domain-specific antibodies activate platelets with features resembling the pathogenic antibodies in heparin-induced thrombocytopenia. Res Sq. 2021;3:rs-462080. https://doi.org/10.21203/rs.3.rs-462080v1.

90. Jevtic SD, Morris AM, Warkentin TE, Pai M. Heparin-induced thrombocytopenia. CMAJ. 2021. https://doi.org/10.1503/cmaj. 210637.

91. Favaloro EJ, Henry BM, Lippi G. The complicated relationships of heparin-induced thrombocytopenia and platelet factor 4 antibodies with COVID-19. Int J Lab Hematol. 2021. https://doi. org/10.1111/ijlh.13582.

92. Kok EY, Srivaths L, Grimes AB, Vogel TP, Sexson Tejtel SK, Muscal E. Immune thrombocytopenia following multisystem inflammatory syndrome in children (MIS-C) - a case series. Pediatr 
Hematol Oncol. 2021:1-5. https://doi.org/10.1080/08880018. 2021.1917737.

93. Aydin FY, Demircan V. Diagnosis and management of coronavirus disease-associated immune thrombocytopenia: a case series. Rev Soc Bras Med Trop. 2021;54:e029.

94. Scarparo P, Lombardi AM, Duner E, Malerba G, Allemand E, Vettore S, et al. Heparin-induced thrombocytopenia: the role of platelets genetic polymorphisms. Platelets. 2012;24(5):362-8.

95. Talotta R. Do COVID-19 RNA-based vaccines put at risk of immune-mediated diseases? Clin Immunol. 2021;224:108665.

96. Cimolai N. Preliminary concerns with vaccine vectors. Mutagenesis. 2020;35(4):359-60.

97. Cimolai N, Do RNA. vaccines obviate the need for genotoxicity studies? Mutagenesis. 2020;20:geaa028. https://doi.org/10.1093/ mutage/geaa028.

98. Hunter PR. Thrombosis after COVID-19 vaccination. BMJ. 2021;373:n958.

99. Tobaiqy M, Elkout H, MacLure K. Analysis of thrombotic adverse reactions of COVID-19 AstraZeneca vaccine reported to the EudraVigilance database. Vaccines. 2021;9(4):393.

100. Shay DK, Gee J, Su JR, Myers TR, Marquez P, Liu R, et al. Safety monitoring of the Janssen (Johnson \& Johnson) COVID-19 vaccine-United States, March-April 2021. MMWR Morb Mortal Wkly Rep. 2021;70(18):680-4.

101. Chan BTB, Bobos P, Odutayo A, Pai M. Meta-analysis of risk of vaccine-induced immune thrombotic thrombocytopenia following ChAdOx1-S recombinant vaccine. medRxiv. 2021. https://doi. org/10.1101/2021.05.04.21256613.

102. Douxfils J, Favresse J, Dogné J-M, Lecompte T, Susen S, Cordonnier $\mathrm{C}$, et al. Hypotheses behind the very rare cases of thrombosis witih thrombocytopenia syndrome after SARS-CoV2 vaccination. Thromb Res. 2021;203:163-71.

103. Hausberg Sørvall I, Daae Horvei K, Leiknes Ernstsen S, Laegreid IJ, Lund S, Henriksen Grønli R, et al. An observational study to identify the prevalence of thrombocytopenia and anti-PF4/ polyanion antibodies in Norwegian health care workers after COVID-19 vaccination. J Thromb Haemost. 2021. https://doi. org $/ 10.1111 /$ jth. 15352 .

104. Tapia MD, Sow SO, Lyke KE, Haidara FC, Diallo F, Doumbia M, et al. Use of ChAd3-EBO-Z Ebola virus in Malian and US adults, and boosting of Malian adults with MVA-BN-Filo: a phase 1, single-blind, randomised trial, a phase $1 \mathrm{~b}$, open-label and double-blind, dose-escalation trial, and a nested, randomized, double-blind, placebo-controlled trial. Lancet Infect Dis. 2016;16(1): 31-42.

105. De Santis O, Audran R, Pothin E, Warpelin-Decrausaz L, Vallotton L, Wuerzner G, et al. Safety and immunogenicity of a chimpanzee adenovirus-vectored Ebola vaccine in healthy adults: a randomized, double-blind, placebo-controlled, dose-finding, phase 1/2a study. Lancet Infect Dis. 2016;16(3):311-20.

106. Ewer K, Rampling T, Venkatraman N, Bowyer G, Wright D, Lambe $\mathrm{T}$, et al. A monovalent chimpanzee adenovirus Ebola vaccine boosted with MVA. N Engl J Med. 2016;374(17):1635-46.

107. Tapia MD, Sow SO, Ndiaye BP, Mbaye KD, Thiongane A, Ndour CT, et al. Safety, reactogenicity, and immunogenicity of a chimpanzee adenovirus vectored Ebola vaccine in adults in Africa: a randomized, observer-blind, placebo-controlled, phase 2 trial. Lancet Infect Dis. 2020;20(6):707-18.

108. Tapia MD, Sow SO, Mbaye KD, Thiongane A, Ndiaye BP, Ndour $\mathrm{CT}$, et al. Safety, reactogenicity, and immunogenicity of a chimpanzee adenovirus vectored Ebola vaccine in children in Africa: a randomized, observer-blind, placebo-controlled, phase 2 trial. Lancet Infect Dis. 2020;20(6):719-30.

109. Greinacher A, Thiele T, Warkentin TE, Weisser K, Kyrie PA, Eichinger S. Thrombotic thrombocytopenia after ChAdOx1
nCov-19 vaccination. N Engl J Med. 2021. https://doi.org/10. 1056/NEJMoa2104840.

110. Schultz NH, Sørvoll IH, Michelsen AE, Munthe LA, LundJohansen F, Ahlen MT, et al. Thrombosis and thrombocytopenia after ChAdOx1 nCoV-19 vaccination. N Engl J Med. https://doi. org/10.1056/NEJMoa2104882.

111. Scully M, Singh D, Lown R, Poles A, Solomon T, Levi M, et al. Pathologic antibodies to platelet factor 4 after ChAdOx $1 \mathrm{nCoV}-19$ vaccination. N Engl J Med. 2021. https://doi.org/10.1056/ NEJMoa2105385.

112. Tiede A, Sachs UJ, Czwalinna A, Werwitzke S, Bikker R, Krauss JK, et al. Prothrombotic immune thrombocytopenia after COVID19 vaccine. Blood. 2021:blood.2021011958. https://doi.org/10. 1181/blood.2021011958.

113. See I, Su JR, Lale A, Woo EJ, Guh AY, Shimabukuro TT, et al. US case reports of cerebral venous sinus thrombosis with thrombocytopenia after Ad26.COV2.S vaccination, March 2 to April 21, 2021. JAMA. 2021. https://doi.org/10.1001/jama. 7517.

114. Schulz JB, Berlit P, Diener HC, Gerloff C, Greinacher A, Klein C, et al. COVID-19 vaccine-associated cerebral venous thrombosis in Germany: a descriptive study. medRxiv. 2021. https://oi.org/ 10.1101/2021.04.30.21256383.

115. Althaus K, Möller P, Uzun G, Singh A, Beck A, Bettag M, et al. Antibody-mediated procoagulant platelets in SARS-CoV-2vaccination associated immune thrombotic thrombocytopenia. Haematologica. 2021. https://doi.org/10.3324/haematol.2021. 279000.

116. Oldenburg J, Klamroth R, Langer F, Albisetti M, von Auer C, Ay $\mathrm{C}$, et al. Diagnosis and management of vaccine-related thrombosis following AstraZeneca COVID-19 vaccination: guidance statement from the GTH. Hamostaseologie. 2021. https://doi.org/10. 1055/a-1469-7481.

117. Mehta PR, Mangion SA, Benger M, Stanton BR, Czyprynska J, Arya $\mathrm{R}$, et al. Cerebral venous sinus thrombosis and thrombocytopenia after COVID-19 vaccination - a report of two UK cases. Brain Behav Immun. 2021:S0889-1591(21)00163-X. https://doi. org/10.1016/j.bbi.2021.04.006.

118. Castelli GP, Pognani C, Sozzi C, Franchini M, Vivona L. Cerebral venous sinus thrombosis associated with thrombocytopenia postvaccination for COVID-19. Crit Care. 2021;25:137.

119. Ankerlund Blauenfeldt R, Risom Kristensen S, Leiknes Ernstsen S, Hilt Kristensen CC, Ziegler Simonsen C, Hvas A-M. Thrombocytopenia with acute ischemic stroke and bleeding in a patient newly vaccinated with an adenoviral vector-based COVID-19 vaccine. J Thromb Haemost. 2021. https://doi.org/ 10.1111/JTH.15347.

120. Franchini M, Testa S, Pezzo M, Glingani C, Caruso B, Terenziani I, et al. Cerebral venous thrombosis and thrombocytopenia postCOVID-19 vaccination. Thromb Res. 2021;202:182-3.

121. Thaler J, Ay C, Gleixner KV, Hauswirth AW, Cacioppo F, Jürgen $\mathrm{G}$, et al. Successful treatment of vaccine-induced prothrombotic immune thrombocytopenia (VIPIT). J Thromb Haemost. 2021. https://doi.org/10.1111/jth.15346.

122. Smith CW, Kardeby C, Di Y, Lowe GC, Lester WA, Watson SP, et al. Platelet activation by vaccine-induced immune thrombotic thrombocytopenia (VITT) patient serum is blocked by COX, P2 $\mathrm{Y}_{12}$ and kinase inhibitors. medRxiv. 2021. https://doi.org/10. 1101/2021.04.24.21255655.

123. Muir K-L, Kallam A, Koepsell SA, Gundabolu K. Thrombotic thrombocytopenia after Ad26.COV2.S vaccination. N Engl J Med. 2021. https://doi.org/10.1056/NEJMc2105869.

124. D'Agostino V, Caranci F, Negro A, Piscitelli V, Tuccillo B, Fasano F, et al. A rare case of cerebral venous thrombosis and disseminated intravascular coagulation temporally associated to the COVID-19 vaccine administration. J Pers Med. 2021;11(4): 285. 
125. Wolf ME, Luz B, Niehaus L, Bhogal P, Bäzner H, Henkes H. Thrombocytopenia and intracranial venous sinus thrombosis after "COVID-19 vaccine AstraZeneca" exposure. J Clin Med. 2021;10(8):1599.

126. Haakonsen HB, Nystedt A. Deep vein thrombosis more than two weeks after vaccination against COVID-19. Tidsskr Nor Laegeforen. 2021;28:141. https://doi.org/10.4045/tidsskr.21. 0274.

127. Garnier M, Curado A, Billoir P, Barbay V, Demeyere M, Dacher J-N. Imaging of Oxford/AstraZeneca COVID-19 vaccine-induced immune thrombotic thrombocytopenia. Diagn Interv Imag. 2021;28:S2211-5684(21)00107-8. https://doi.org/10.1016/j.diii. 2021.04.005.

128. Yocum A, Simon EL. Thrombotic thrombocytopenic purpura after Ad26.COVs-S vaccination. Am J Emerg Med. 2021:S07356757(21)00376-4. https://doi.org/10.1016/ajem.2021.05.001.

129. Jamme M, Mosnino E, Hayon J, Franchineau G. Fatal cerebral venous sinus thrombosis after COVID-19 vaccination. Intensive Care Med. 2021;13:1-2. https://doi.org/10.1007/s00134-02106425-y.

130. Jones M, Boisvert A, Landry J, Petrasek PF. Limb ischemia and pulmonary artery thrombosis after the ChAdOx $1 \mathrm{nCoV}-19$ (Oxford-AstraZeneca) vaccine: a case of vaccine-induced immune thrombotic thrombocytopenia. CMAJ. 2021. https://doi.org/10. 1503/cmaj.210795.

131. Geeraerts T, Montastruc F, Bonneville F, Mémier V, Raposo N, and the Toulouse Vitt Study Group. Oxford-AstraZeneca COVID19 vaccine-induced cerebral venous thrombosis and thrombocytopenia: a missed opportunity for a rapid return of experience. Anaesth Crit Care Pain Med. 2021;2021:100889. https://doi.org/ 10.1016/j.accpm.2021.100889.

132. Ryan E, Benjamin D, McDonald I, Barrett A, McHugh J, Ryan K, et al. AZD1222 vaccine-related coagulopathy and thrombocytopenia without thrombosis in a young female. Br J Haematol. 2021. https://doi.org/10.1111/bjh.17530.

133. Karron RA, Key NS, Sharfstein JM. Assessing a rare and serious adverse event following administration of the Ad26.COV2.S vaccine. JAMA. 2021. https://doi.org/10.1001/jama.2021.7637.

134. Gupta A, Sardar P, Cash ME, Milani RV, Lavie CJ. COVID-19 vaccine-induced thrombosis and thrombocytopenia - a commentary on an important and practical clinical dilemma. Prog Cardiovasc Dis. 2021:S0033-0620(21)00050-5. https://doi.org/ 10.1016/j.pcad.2021.05.001

135. Sadoff J, Davis K, Douoguih M, et al. Thrombotic thrombocytopenia after Ad26.COV2.S vaccination - response from the manufacturer. N Eng1 J Med. 2021. https://doi.org/10.1056/ NEJMc2106075.

136. Voysey M, Costa Clemens SA, Madhi SA, Weckx LY, Folegatti PM, Aley PK, et al. Safety and efficacy of the ChAdOx $1 \mathrm{nCoV}-19$ vaccine (AZD12222) against SARS-CoV-2: an interim analysis of four randomised controlled trials in Brazil, South Africa, and the UK. Lancet. 2021;397:99-111.

137. Pawlowski C, Rincón-Hekking J, Awasthi S, Pandey V, Lenehan $\mathrm{P}$, Venkatakrishnan AJ, et al. Cerebral venous sinus thrombosis (CVST) is not significantly linked to COVID-19 vaccines or nonCOVID vaccines in a large multi-state US health system. medRxiv. 2021. https://doi.org/10.1101/2021.04.20.21255806.

138. Sissa C, Al-Khaffaf A, Frattini F, Gaiardoni R, Mimiola E, Montorsi P, et al. Relapse of thrombotic thrombocytopenic purpura after COVID-19 vaccine. Tranfus Apher Sci 2021;103145. doi: https://doi.org/10.1016/j.transci.2021.103145

139. Al-Mufti F, Amuluru K, Sahni R, Bekelis K, Karimi R, Ogulnick $\mathrm{J}$, et al. Cerebral venous thrombosis in COVID-19: a New York Metropolitan cohort study. AJNR Am J Neuroradiol. 2021. https:// doi.org/10.3174/ajnr.A7134.
140. Dotan A, Shoenfeld Y. Perspectives on vaccine induced thrombotic thrombocytopenia. J Autoimmun. 2021;121:1-2663.

141. Kowarz E, Krutzke L, Reis J, Bracharz S, Kochanek S, Marschalek R. "Vaccine-induced COVID-10 mimicry" syndrome: splice reactions with the SARS-CoV-2 Spike open reading fram result in Spike protein variants that may cause thromboembolic events in patients immunized with vector-based vaccines. Res Sq. 2021. https://doi.org/10.21203/rs.3.rs-558954/v1.

142. Nguyen T-H, Medvedev N, Delcea M, Greinacher A. Anti-platelet factor 4/polyanion antibodies mediate a new mechanism of autoimmunity. Nat Commun. 2017;8:14945.

143. Katzav A, Kivity S, Blank M, Shoenfeld Y, Chapman J. Adjuvant immunization induces high levels of pathogenic antiphospholipid antibodies in genetically prone mice: another facet of ASIA syndrome. Lupus. 2010;21(2):210-8.

144. Schofield J, Chemali K. Intravenous immunoglobulin therapy in refractory autoimmune dysautonomias: a retrospective analysis of 38 patients. Am J Ther. 2019;26(5):e570-82.

145. Kadkhoda K. Post adenoviral-based COVID-19 vaccines thrombosis: a proposed mechanism. J Thromb Haemost. 2021. https:// doi.org/10.1111/jth.15348.

146. Cichon G, Schmidt HH, Benhidjeb T, Löser P, Ziemer S, Haas R, et al. Intravenous administration of recombinant adenoviruses causes thrombocytopenia, anemia and erythroblastosis in rabbits. J Gene Med. 1999;1(5):360-71.

147. Lozier JN, Csako G, Mondoro TH, Krizek DM, Metzger ME, Costello R, et al. Toxicity of a first-generation adenoviral vector in rhesus macaques. Hum Gene Ther. 2002;13(1):113-24.

148. Wolins N, Lozier J, Eggerman TL, Jones E, Aguilar-Córdova E, Vostal JG, et al. Intravenous administration of replicationincompetent adenovirus to rhesus monkeys induces thrombocytopenia by increasing in vivo platelet clearance. $\mathrm{Br} \mathrm{J}$ Haematol. 2003;123(5):903-5.

149. Liu Q, Zaiss AK, Colarusso P, Patel K, Haljan G, Wickham TJ, et al. The role of capsid-endothelial interactions in the innate immune response to adenovirus vectors. Hum Gene Ther. 2003;14(7):627-43.

150. Schnell MA, Zhang Y, Tazelaar J, Gao GP, Yu QC, Qian R, et al. Activation of innate immunity in nonhuman primates following intraportal administration of adenoviral vectors. Mol Ther. 2001;3(5 Pt 1):708-22.

151. Morral N, O’Neal WK, Rice K, Leland M, Piedra PA, AguilarCórdova E, et al. Lethal toxicity, severe endothelial injury, and a threshold effect with high doses of an adenoviral vector in baboons. Hum Gene Ther. 2002;13(1):143-54.

152. O'Neal WK, Zhou H, Morral N, Aguilar-Cordova E, Pestaner J, Langston $\mathrm{C}$, et al. Toxicological comparison of E2a-deleted and first-generation adenoviral vectors expressing alpha1-antitrypsin after systemic delivery. Hum Gene Ther. 1998;9(11):1587-98.

153. Varnavski AN, Calcedo R, Bove M, Gao G, Wilson JM. Evaluation of toxicity from high-dose systemic administration of recombinant adenovirus vector in vector-naïve and preimmunized mice. Gene Ther. 2005;12(5):427-36.

154. Lozier JN, Metzger ME, Donahue RE, Morgan RA. Adenovirusmediated expression of human coagulation factor IX in the rhesus macaque is associated with dose-limiting toxicity. Blood. 1999;94(12):3968-75.

155. Herman JR, Adler HL, Aguilar-Cordova E, Rojas-Martinez A, Woo S, Timme TL, et al. In situ gene therapy for adenocarcinoma of the prostate: a phase I clinical trial. Hum Gene Ther. 1999;10(7):1239-49.

156. Malaeb BS, Gardner TA, Margulis V, Yang L, Gillenwater JY, Chung LWK, et al. Elevated activated partial thromboplastin time during administration of first-generation adenoviral vectors for gene therapy for prostate cancer: identification of lupus anticoagulants. Urology. 2005;66(4):830-4. 
157. Pesonen S, Nokisalmi P, Escutenaire S, Särkioja M, Raki M, Cerullo V, et al. Prolonged systemic circulation of chimeric oncolytic adenovirus AD5/3-COX2L-D24 in patients with metastatic and refractory solid tumors. Gene Ther. 2010;17(7):892904.

158. Freytag SO, Stricker H, Lu M, Elshaikh M, Aref I, Pradhan D, et al. Prospective randomized phase 2 trial of intensity modulated radiation therapy with or without oncolytic adenovirus-mediated cytotoxic gene therapy in intermediate-risk prostate cancer. Int $\mathrm{J}$ Radiat Oncol Biol Phys. 2014;89(2):268-76.

159. Stone D, Liu Y, Shayakhmetov D, Li Z-Y, Ni S, Lieber A. Adenovirus-platelet interaction in blood causes virus sequestration to the reticuloendothelial system of the liver. J Virol. 2007;81(9):4866-71.

160. Badbaran A, Mailer R, Dahlke C, Woens J, Fathi A, Mellinghoff $\mathrm{SC}$, et al. Digital PCR to quantify ChAdOx $1 \mathrm{nCoV}-19$ copies in blood and tissues. medRxiv. https://doi.org/10.1101/2021.05.28. 446155.

161. Othman M, Labelle A, Mazzetti I, Elbatamy HS, Lillicrap D. Adenovirus-induced thrombocytopenia: the role of von Willebrand factor and P-selectin in mediating accelerated platelet clearance. Blood. 2007;109(7):2832-9.

162. Gupalo E, Kuk C, Qadura M, Buriachkovskaia L, Othman M. Platelet-adenovirus vs. inert particles interaction: effect on aggregation and the role of platelet membrane receptors. Platelets. 2013;24(5):383-91.

163. Eggerman TL, Mondoro TH, Lozier JN, Vostal JG. Adenoviral vectors do not induce, inhibit, or potentiate human platelet aggregation. Hum Gene Ther. 2002;13(1):125-8.

164. Hofherr SE, Mok H, Gushiken FC, Lopez JA, Barry MA. Polyethylene glycol modification of adenovirus reduces platelet activation, endothelial cell activation, and thrombocytopenia. Hum Gene Ther. 2007;18(9):837-48.

165. Shimony N, Elkin G, Kolodkin-Gal D, Krasny L, Urieli-Shoval S, Haviv YS. Analysis of adenoviral attachment to human platelets. Virol J. 2009;6:25.

166. Seregin SS, Aldhamen YA, Appledorn DM, Hartman ZC, Schuldt NJ, Scott J, et al. Adenovirus capsid-display of the retro-oriented human complement inhibitor DAR reduces Ad vector-triggered immune responses in vitro and in vivo. Blood. 2010;116(10): 1669-77.

167. Kiang A, Hartman ZC, Everett RS, Serra D, Jiang H, Frank MM, et al. Multiple innate inflammatory responses induced after systemic adenovirus vector delivery depend on a functional complement system. Mol Ther. 2006;14(4):588-98.

168. Xu Z, Smith JS, Tian J, Byrnes AP. Induction of shock after intravenous injection of adenovirus vectors: a critical role for platelet-activating factor. Mol Ther. 2010;18(3):609-16.

169. Goldman M, Hermans C. Thrombotic thrombocytopenia associated with COVID-19 infection or vaccination: possible paths to platelet factor 4 autoimmunity. PLoS Med. 2021;18(5):e1003648.

170. McGonagle D, De Marco G, Bridgewood C. Mechanisms of immunothrombosis in vaccine-induced thrombotic thrombocytopenia (VITT) compared to natural SARS-CoV-2 infection. J Autoimmun. 2021;121:102662.

171. Anderson WF. Adenoviral vector safety and concern. Hum Gene Ther. 2002;13(1):1.

172. NIH Recombinant DNA Advisory Committee. Assessment of adenoviral vector safety and toxicity: report of the National Institutes of Health Recombinant DNA Advisory Committee. Hum Gene Ther. 2002;13(2):3-13

173. Ondondo B, Abdul-Jawad S, Roshorm Y, Bridgeman A, Hanke T. Vector delivery-dependent effect of human tissue plasminogen activator signal peptide on vaccine induction of T cells. J HIV AIDS. 2016;2(4). https://doi.org/10.16966/2380-5536.130.
174. Almuqrin A, Davidson AD, Kavanagh Williamson M, Lewis PA, Heesom KJ, et al. SARS-CoV-2 vaccine ChAdOx1 nCoV-19 infection of human cell lines reveals low levels of viral backbone gene transcription alongside very high levels of SARS-CoV-2 S glycoprotein gene transcription. Genitourin Med. 2021;13:43.

175. Bos R, Rutten L, van der Lubbe JEM, Bakkers MJG, Hardenberg G, Wegmann F, et al. Ad26 vector-based COVID-19 vaccine encoding a prefusion-stabilized SARS-CoV-2 Spike immunogen induces potent humoral and cellular immune responses. NPJ Vaccines. 2020;5:91.

176. Klug M, Lazareva O, Kirmes K, Rosenbaum M, Lukas M, Weidlich $\mathrm{S}$, et al. Platelet expression and reactivity after BNT162b2 vaccine administration. medRxiv. https://doi.org/10. 1101/2021.05.18.21257324.

177. Abzug MJ, Levin MJ. Neonatal adenovirus infection: four patients and review of the literature. Pediatrics. 1991;87(6):890-6.

178. Sakata H, Taketazu G, Nagaya K, Shirai M, Sugai R, Ikegami K, et al. Outbreak of severe infection due to adenovirus type 7 in a paediatric ward in Japan. J Hosp Infect. 1998;39(3):207-11.

179. Lin M-R, Yang S-L, Gong Y-N, Kuo C-C, Chiu C-H, Chen C-J, et al. Clinical and molecular features of adenovirus type 2, 3, and 7 infections in children in an outbreak in Taiwan, 2011. Clin Microbiol Infect. 2017;23(2):110-6.

180. Lurhuma AZ, Riccomi H, Masson PL. The occurrence of circulating immune complexes and viral antigens in idiopathic thrombocytopenic purpura. Clin Exp Immunol. 1977;28(1):49-55.

181. Murray J. Adenovirus and childhood immune thrombocytopenic purpura. Am J Hematol. 1994;47(1):64-5.

182. Murata T, Hori M, Lee S, Nakamura A, Kohama K, Karaki H, et al. Vascular endothelium has a local anti-adenovirus vector system and glucocorticoid optimizes its gene transduction. Arterioscler Thomb Vasc Biol. 2005;25(9):1796-803.

183. Laakkonen JP, Engler T, Romero IA, Weksler B, Couraud P-O, Kreppel F, et al. Transcellular targeting of fiber- and hexonmodified adenovirus vectors across the brain microvascular endothelial cells in vitro. PLoS One. 2012;7(9):e45977.

184. Kaliberov SA, Kaliberova LN, Lu JH, Preuss MA, Barnes JA, Stockard CR, et al. Retargeting of gene expression using endothelium specific hexon modified adenoviral vector. Virology. 2013;447(1-2):312-25.

185. Lu ZH, Kaliberov S, Zhang J, Muz B, Azab AK, Sohn RE, et al. The myeloid-binding peptide adenoviral vector enables multiorgan vascular endothelial gene targeting. Lab Investig. 2014;94(8):881-92.

186. Dakin RS, Parker AL, Delles C, Nicklin SA, Baker AH. Efficient transduction of primary vascular cells by the rare adenovirus serotype 49 vector. Hum Gene Ther. 2015;26(5):312-9.

187. Buggio M, Towe C, Annan A, Kaliberov S, Lu ZH, Stephens C, et al. Pulmonary vasculature directed adenovirus increases epithelial lining fluid alpha-1 antitrypsin levels. J Gene Med. 2016;18(13):38-44.

188. Nazy I, Sachs UJ, Arnold DM, McKenzie SE, Choi P, Althaus K, et al. Recommendations for the clinical and laboratory diagnosis of vaccine-induced immune thrombotic thrombocytopenia (VITT) for SARS-CoV-2 infections: communication from the ISTH SSC Subcommittee on Platelet Immunology. J Thromb Haemost. 2021. https://doi.org/10.1111/JTH.15341.

189. Nazy I, Sachs UJ, Arnold DM, McKenzie SE, Choi P, Althaus K, et al. Recommendations for the clinical and laboratory diagnosis of VITT against COVID-19: communication from the ISTH SCC Subcommittee on Platelet Immunology. J Thromb Haemost. 2021. https://doi.org/10.1111/jth.15341.

190. FACME Working Group. Diagnostic and treatment recommendations from the FACME ad-hoc expert working group on the management of cerebral venous sinus thrombosis associated with 
COVID-19 vaccination. Neurologia. 2021:S01134853(21)00083-9.

191. Platton S, Bartlett A, MacCallum P, Makris M, McDonald V, Singh D, et al. Evaluation of laboratory assays for anti-platelet factor 4 antibodies after ChAdOx1 nCOV-19 vaccination. J Thromb Haemost. 2021. https://doi.org/10.1111/jth.15362.

192. Karnam A, Lacroix-Desmazes S, Kaveri SV, Bayry J. Vaccineinduced prothrombotic immune thrombocytopenia (VIPIT): consider IVIG batch in the treatment. J Thromb Haemost. 2021. https://doi.org/10.1111/jth.15361.

193. Graf T, Thiele T, Klingebiel R, Greinacher A, Schäbitz W-R, Greeve I. Immediate high-dose intravenous immunoglobulins followed by direct thrombin-inhibitor treatment is crucial for survival in SARS-COVID-19-adenoviral vector vaccine-induced immune thrombotic thrombocytopenia VITT with cerebral sinus venous and portal vein thrombosis. J Neurol. 2021. https://doi.org/ 10.1007/s00415-021-10599-2.

194. Bersinger S, Lagarde K, Marlu R, Pernod G, Payen J-F. Using nonheparin anticoagulant to treat a near-fatal case with multiple venous thrombotic lesions during ChAdOx $1 \mathrm{nCoV}-1$ vaccinationrelated vaccine-induced immune thrombotic thrombocytopenia. Crit Care Med. 2021. https://doi.org/10.1097/CCM. 0000000000005105 .

195. Von Hundelhausen P, Lorenz R, Siess W, Weber C. Vaccineinduced immune thrombotic thrombocytopenia (VITT): targeting pathomechanisms with Bruton tyrosine kinase inhibitors. Thromb Haemost. 2021. https://doi.org/10.1055/a-1481-3039.

196. MacNeil JR, Su JR, Broder KR, Guh AY, Gargano JW, Wallace $\mathrm{M}$, et al. Updated recommendations from the Advisory Committee on Immunization Practices for use of the Janssen (Johnson \& Johnson) COVID-19 vaccine after reports of thrombosis with thrombocytopenia syndrome among vaccine recipients - United States, April, 2021. MMWR Morb Mortal Wkly Rep. 2021;70(17):651-6.

197. Cimolai N. A minimalist strategy towards temporarily defining protection for COVID-19. SN Compr Clin Med. 2020;19:1-8. https://doi.org/10.1007/s42399-020-00533-4.

198. Cimolai N. Applying immune instincts and maternal intelligence from comparative microbiology to COVID-19. SN Compr Clin Med. 2020;9:1-14. https://doi.org/10.1007/s42399-020-00634-0.

199. Cimolai N. Why passive immunity should and will work for COVID-19 for some. Clin Hematol Int. (In press).

200. Cimolai N. Complicating infections associated with common endemic human respiratory coronaviruses. Health Secur. 2020;2020: 11. https://doi.org/10.1089/hs.2020.0067.

Publisher's Note Springer Nature remains neutral with regard to jurisdictional claims in published maps and institutional affiliations. 